\title{
ENTRE AS DIMENSÕES "ESCONDIDAS" DO LETRAMENTO ACADÊMICO E OS PRESUMIDOS SOCIAIS DO GÊNERO ARTIGO DE PESQUISA NAS DIRETRIZES PARA AUTORES DE PERIÓDICOS EM CIÊNCIA DA COMPUTAÇÃO
}

\author{
BETWEEN "HIDDEN" FEATURES OF ACADEMIC LITERACY AND \\ SOCIAL ASSUMPTIONS OF THE GENRE RESEARCH ARTICLE \\ WITHIN AUTHORS' GUIDELINES OF COMPUTER SCIENCE \\ JOURNALS
}

Bruna Gabriela Augusto Marçal Vieira'

RESUMO: O presente trabalho analisou textos de diretrizes para autores de seis periódicos em Ciência da Computaçâo, com o objetivo de verificar a existência de dimensōes "escondidas" do letramento, as quais podem ocultar informaçóes relevantes para uma melhor elaboraçáo dos textos de acordo com o esperado pelas revistas. A partir de uma análise etnográfica discursiva, a qual possibilitou a compreensâo dos conceitos de língua, texto e gênero que fundamentam as práticas de letramento das revistas, alguns ocultamentos foram identificados e relacionados a presumidos sociais do gênero artigo de pesquisa. A análise revelou, dentre outras coisas, que os periódicos concentram as orientaçōes, em grande parte, nos aspectos formais e estruturais do texto, deixando "escondidas" dimensōes do letramento relacionadas a conteúdo, retórica e ideologia, por exemplo. Embasados por uma concepçáo de língua, texto e gênero que se aproxima à abordagem de ensino de escrita identificada por Lea e Street (1998) como Socializaçâo Acadêmica, esses periódicos partem do presumido de que as especificidades do discurso acadêmico săo únicas e transferíveis de gênero para gênero, independentemente dos eventos de letramento em questăo. Assim, contam com um conhecimento do letramento acadêmico que pesquisadores menos experientes podem ainda nâo reconhecer, dificultando a iniciaçăo desses novatos nas discussôes acadêmicas.

PALAVRAS-CHAVE: Letramento acadêmico; dimensóes "escondidas" do letramento acadêmico; presumidos sociais dos gêneros do discurso; artigo de pesquisa; diretrizes para autores

Licenciada em Letras (habilitaçâo Português e Francês) pela Universidade Estadual Paulista (UNESP) "Júlio de Mesquita Filho". Possui mestrado em Linguística Aplicada, na área de concentraçăo em Ensino e Aprendizagem de Línguas, pela mesma instituiçăo, desenvolvido com bolsa da Coordenaçăo de Aperfeiçoamento de Pessoal de Nível Superior (CAPES). Atualmente é aluna de doutorado do programa de Estudos Linguísticos da UNESP, e desenvolve pesquisa na área de Linguística Aplicada, com apoio da Fundaçáo de Amparo à Pesquisa do Estado de Săo Paulo (FAPESP - Processo Nº 2015/11088-1). Email: brugabiguto@yahoo.com.br ou brunagabliela@gmail.com 
ABSTRACT: This paper presents the analysis of texts of Authors' Guidelines of six Computer Science journals. The research aimed at verifying the existence of "hidden" features of academic literacy in the texts, which may hide relevant information to the production of papers according to what is expected by the journals. Through a discursive ethnographic analysis, which enabled us to understand the concepts of language, text and genre that grounds the literacy practices of the journals, some "hidden" features were identified and related to social assumptions of the genre research article. The analysis showed, among other things, that the journals center the guidelines, mostly, in formal and structural aspects of the text, failing to approach some literacy features, such as content, rhetoric and ideology. Based on a concept of language, text and genre, which is very similar to the Academic Socialization approach to teaching writing, identified by Lea and Street (1998), the journals depart from the social assumption that academic discourse specificities are the same for all academic genres. Thus, they count on some type of knowledge from the authors, which inexperienced researchers may not have yet, making it more difficult for these novices to engage in academic discussion in their field.

KEY-WORDS: Academic literacy; "hidden" features of academic literacy; social assumptions of discourse genres; research article; authors ' guidelines

\section{INTRODUÇÃO}

Quando o assunto é escrita na universidade, certamente a primeira coisa que se pensa é em artigo de pesquisa. Embora o ambiente acadêmico seja constituído de diversos outros gêneros, orais e escritos, que se relacionam nas esferas institucional, pedagógica e científica, a grande necessidade de se publicar trabalhos acadêmicos força a todos os atuantes na academia a se preocuparem com a publicaçáo do maior número possível de artigos. Conforme Clapham (2005), a publicaçâo de artigos se consiste em uma prática fundamental para a atividade de pesquisa, uma vez que eles sâo "o fertilizante que estimula a ideia em outros pesquisadores (390)."2 De fato, esta prática facilita a comunicaçăo entre pesquisadores de todo o mundo, funcionando como uma engrenagem para o fazer científico. No entanto, mais do que uma forma de colaboraçáo científica, a publicaçáo acadêmica tem servido como um meio de mensurar a qualidade do trabalho dos pesquisadores, de maneira que um maior número de publicaçóes representa uma maior produtividade.

A máxima Publish or Perish reflete adequadamente esta filosofia. A quantidade de publicaçăo năo é preocupaçăo apenas dos pesquisadores. Universidades, agências de fomento e periódicos também sâo avaliados pela quantidade de publicaçôes e de citaçōes, colocando, dessa forma, ainda mais pressăo para a publicaçâo de artigos por parte dos pesquisadores. Esta grande necessidade de publicaçăo năo reflete, no entanto, o tamanho do interesse e investimento dispensado na preparaçáo dos pesquisadores para a comunicaçấo acadêmica, principalmente no Brasil. Poucos cursos de um número ainda menor de universidades brasileiras oferecem cursos de redaçâo

Traduçâo livre. No original: "They [publications] are the fertilizer [...] that stimulates ideas in other scientists" (CLAPHAM, 2005, p. 390). 
acadêmica (ARANHA, 2009), e, quando oferecem, é possível que se dediquem ao ensino de formataçấo de textos, apenas, como verificado na disciplina Metodologia Científica - Redaçâo e Documentaçâo Técnica do curso de Bacharelado em Ciência da Computaçăo de uma universidade pública paulista (VIEIRA, 2016).

Isto ocorre porque a herança de uma tradiçăo estruturalista de ensino da escrita, definida como modelo autônomo de letramento por Street (1984), ainda fundamenta as práticas educacionais em nosso país, especialmente no Ensino Superior e em áreas outras que náo da linguagem. É comum em áreas tecnológicas, como a da disciplina mencionada acima, que pesquisadores da própria área assumam as aulas de redaçâo, pois há uma crença de que graduandos e pós-graduandos, após tantos anos de ensino de português nos ensinos fundamental e médio, devam saber escrever e que, portanto, é necessária apenas uma instruçăo a respeito da formataçăo dos textos que devem produzir no ambiente acadêmico. Este modelo autônomo de letramento, como bem explica Street, toma a escrita como uma habilidade cognitiva que, uma vez dominada, é facilmente reproduzida e adequadamente transferível de um contexto de uso ao outro.

A linguagem, enquanto prática social (BAKHTIN, 1981/1997), é fundamentalmente marcada pela presença do outro, portanto, como relembra Magalhâes (2012a), a escrita também é uma prática social, situada em um contexto sócio-histórico e, assim, pode diferir "segundo a relaçáo que se estabelece entre a dimensâo discursiva e outras dimensóes das práticas" (p. 28). Essas diferenças nos usos da linguagem, ainda pouco abordadas em nível universitário e, por conseguinte, pouco percebidas pelos alunos, sâo as principais responsáveis pela grande dificuldade que os pesquisadores iniciantes encontram em publicar artigos. Mais do que conhecimento de gramática e formataçăo de textos, é preciso, portanto, incluir nas aulas de redaçăo acadêmica discussôes sobre o que é a academia, sua cultura, sua prática e seu discurso (MOTTAROTH, 1999), de forma a evidenciar as especificidades do contexto que geram as especificidades nos usos da linguagem.

Lea e Street (1998), ao investigarem as diversas abordagens com que se dava o ensino de redaçáo no ensino superior, verificaram a existência de dois tipos: Habilidades de Estudo e Socializaçăo Acadêmica. O primeiro refere-se à abordagem descrita acima, e o segundo, andando em direçấo a uma abordagem para fins específicos (SWALES, 1990), reconhece o ambiente acadêmico como um local de práticas singulares, diferentes das da escola regular, e que, assim, possui um discurso próprio. O problema é que, segundo esta abordagem, há a existência de um "discurso acadêmico" o qual, uma vez compreendido, seria facilmente reproduzido em toda atividade de escrita acadêmica, inclusive entre disciplinas. Assim, considerando o papel social da escrita, os pesquisadores propóem uma abordagem chamada Letramentos Acadêmicos.

Segundo esta abordagem, a gramática e a cultura acadêmica no geral săo tăo importantes quanto a cultura da disciplina em específico. Questôes institucionais, departamentais, políticas, econômicas e sociais refletem diretamente as práticas acadêmicas em cada disciplina e, consequentemente, as práticas orais e escritas. Aulas de redaçâo acadêmica, portanto, devem sair do nível da frase e da formataçâo do texto e discorrer sobre as práticas de letramento, o que, como pontua Magalhăes (2012b), demanda análise de poder. Segundo a autora, "a ideia de letramento implica 
o estudo da escrita e seu contexto, nâo só seu contexto imediato, mas também e principalmente o contexto amplo, de cultura e sociedade, ideologia e poder" (161).

Os gêneros do discurso aparecem como uma maneira palpável de realizar este trabalho em sala de aula, pois, por meio do estudo dos gêneros, é possível aliar análise linguística-textual à contextual. Segundo Street (2010), o estudo de gêneros permite năo só verificar padrôes de discurso em áreas específicas, mas também e permite realizar pesquisas de diversos níveis, levando em consideraçăo a variedade de textos e práticas que envolvem a escrita de universitários, de forma a compreender e dar o melhor suporte possível para este processo. Algumas das pesquisas apontadas pelo pesquisador săo: análise do feedback de professores à escrita dos alunos e as suas implicaçóes para o processo de construçấo de sentido e para questóes de identidade; análise da natureza dos enunciados em trabalhos de alunos de mestrado e as implicaçôes sobre como esses enunciados săo elaborados para que os alunos os compreendam; análise da natureza textual de debates online de alunos e como os alunos integram esses debates em seus trabalhos etc. (p. 6).

Em seu trabalho com gêneros, Street (2010) propôs uma atividade para ser desenvolvida em sala de aula, a qual propóe a abordagem de aspectos envolvidos na produçăo e circulaçăo do gênero, geralmente negligenciados durante o ensino de escrita. Ao lecionar uma disciplina de letramentos na Faculdade de Educaçăo da Universidade da Pensilvânia, o pesquisador trabalhou com uma lista, elaborada inicialmente por ele e, posteriormente, em colaboraçáo com os alunos, constituída de conceitos relacionados a critérios de avaliaçăo de artigos de pesquisa. O objetivo era tentar abordar questóes envolvidas no processo de avaliaçăo dos artigos as quais costumam ser desconsideradas em aulas de escrita. Essas questōes, chamadas pelo autor de "dimensôes 'escondidas' do letramento", devem também ser de conhecimento dos alunos, para que eles produzam seus textos atentando-se a elas, e, assim, amentem suas chances de terem seus trabalhos publicados.

O texto do autor chama a atençăo para questôes relevantes que pouco têm sido abordadas por professores em aulas de letramento. Dentre elas está "voz", ou seja, a inserçăo da voz do autor e o grau de envolvimento com que escreve. Esta desconsideraçấo, conforme Corrêa (2011), nem sempre é proposital, ou seja, năo se trata de escolhas conscientes dos professores. Segundo o pesquisador, "a temática em que o gênero se inclui, o quadro institucional em que é produzido e as perspectivas que, de fora do texto, o orientam sáo fatores que podem, em parte, estar presumidos no gênero" (p. 344). Em outras palavras, é possível que professores tomem como já sabidas, ou como "presumido social", determinadas características do gênero. Por exemplo, o autor contesta a ideia de que a temática proposta para um texto, mesmo que por alunos de pós-graduaçăo em determinada área do conhecimento, seja algo percebido por todos da mesma maneira. Para ele, "um tema pode ser anunciado e suposto como tratado, mas, a depender das implicaçōes da temática maior em que se inclui, essa presunçăo pode năo se cumprir explicitamente" (idem, ibidem).

Neste sentido, além das aulas de letramento no ensino superior, entra em foco periódicos científicos e as orientaçôes que eles disponibilizam para os autores para a elaboraçâo de artigos a serem submetidos. De maneira geral, todas as revistas submetem os artigos a uma avaliaçăo entre pares, o que, para Clapham (2005), é outra vantagem relacionada à temática Publish or Perish. Segundo o autor, a análise 
de pares é muito útil e contribui náo só para a escrita acadêmica, mas também para as práticas de pesquisa de um pesquisador. $O$ fato é que, apesar dos benefícios apontados pelo autor, a análise entre pares consiste em um grande obstáculo para a publicaçăo e, neste caso, tanto para pesquisadores iniciantes quanto para os mais experientes. Isso porque, em sua maioria, os pareceristas săo também pesquisadores, convidados pela revista para avaliarem os manuscritos dos colegas, o que significa uma multiplicidade de conceitos e práticas de letramento que tornaria difícil estabelecer um padrăo de critérios de avaliaçăo. Neste ínterim que se revela a importância das informaçóes contidas nas Diretrizes para Autores. Presentes em todos os websites de todos os periódicos online, as diretrizes săo responsáveis por informar os autores sobre as especificidades da revista e, assim, o que é esperado do texto a ser submetido.

Visando a contribuir para as pesquisas em letramento, especificamente para a melhor preparaçâo de pesquisadores para a publicaçăo de artigos, a presente pesquisa analisou as diretrizes para autores de seis periódicos da área de Ciência da Computaçâo. As revistas escolhidas constavam com avaliaçâo Al da CAPES, que avalia a qualidade da publicaçăo; e Q1 do $\mathrm{SJR}_{r}{ }^{3}$ que avalia seu fator de impacto. Ademais, todos aceitam publicaçăo de universitários. O objetivo da análise foi verificar possíveis dimensōes "escondidas" do letramento que podem vir a dificultar a escrita de artigos de acordo com o esperado pelas revistas. O foco da análise foi as informaçōes a respeito dos direitos dos autores e políticas de autoria, bem como as orientaçôes para a elaboraçâo de manuscritos e os processos de submissăo. A partir de uma análise etnográfica discursiva (CORREAA, 2011), buscou-se i) identificar os conceitos de língua, texto e gênero que fundamentam as práticas de letramento das revistas e, portanto, as orientaçôes oferecidas aos autores; e ii) investigar a existência de dimensóes "escondidas" do letramento ao longo dessas orientaçóes, e relacioná-las, com base nos conceitos previamente identificados, a presumidos sociais do gênero.

\section{DIMENSÕES "ESCONDIDAS" DO LETRAMENTO E OS PRESUMIDOS SOCIAIS DOS GÊNEROS DO DISCURSO}

A pesquisa apresentada no presente trabalho tem como principal aporte teórico o conceito de letramento, tal qual desenvolvido pelos Novos Estudos do Letramento (NEL). Fundamental para a compreensâo deste conceito é a noçăo de linguagem como prática social e de dialogismo enquanto aspecto constitutivo da escrita. Komesu (2012) explica que essa noçấo de linguagem, desenvolvida por Bakhtin e seu ciclo de estudos em 1981, trata-se de uma concepçâo ideológica, uma vez que, recuperando Fiorin (2006 apud KOMESU, 2012), nosso discurso se relaciona diretamente com outros discursos, e nâo diretamente com as coisas. Conforme a autora, é essa relaçâo entre os discursos que configura o dialogismo. Neste sentido, toda prática de escrita, e também de leitura, é igualmente dialógica, pois, como sinaliza a pesquisadora, "a produçáo de textos ou de enunciados nesse quadro é entendida como significante,

Scientific Journal Rankings 
numa significaçăo que produz trabalho, no movimento entre sujeito, o outro e o contexto sociohistórico" (p. 80).

Esta perspectiva social do conceito de linguagem e texto escrito provocou inquietaçăo em pesquisadores de diversas áreas, culminando em estudos e proposiçôes de ensino diferentes do modelo tradicional desenvolvido até entăo. 0 conceito de letramento, que embasa este trabalho, é resultado dessas inquietaçóes. Street (1984), interessado em investigar o modo como uma perspectiva social no tratamento da linguagem poderia acarretar mudanças nas formas de se ensinar letramento na sala de aula, deu início aos estudos dessa nova corrente teórica - os NEL.

A seguir, alguns dos conceitos principais desenvolvidos pelos NEL serăo abordados, com o objetivo de traçar o entendimento sobre o que se trata o conceito de dimensóes "escondidas" do letramento - objeto de investigaçâo deste trabalho.

\section{Modelo Autônomo de Letramento X Modelo Ideológico de letramento}

O conceito de letramento, apoiado em uma concepçâo de linguagem como prática social e de interaçôes escritas como uma atividade dialógica, abarca todo e qualquer uso que indivíduos de determinada comunidade façam da linguagem escrita, seja com objetivos de escrita ou de leitura. Neste sentido, Oliveira (2009) ressalta que o letramento consiste em um fenômeno social, pois cada comunidade possui diferentes padrôes de letramento, os quais săo influenciados por condiçôes locais, tais como aspectos socioeconômicos, históricos, culturais, políticos e educacionais. Mas que também possui uma dimensâo individual, uma vez que é utilizado por indivíduos que pertencem a determinadas comunidades, os quais possuem específicas histórias e experiências de vida.

Enquanto um fenômeno social, é possível afirmar que năo há apenas um tipo de letramento, ou seja, um tipo correto de escrita e leitura, aplicável a toda situaçâo de interaçáo humana. É preciso que se fale, portanto, de letramentos, no plural, como bem propóem os NEL. Ademais, a dimensáo individual dos letramentos evidencia a nâo imparcialidade no uso da linguagem escrita, isto é, ao escrever, toda a carga históricocultural do indivíduo, a qual constitui sua identidade, fundamenta escolhas, muitas vezes inconscientes, que determinam sua posiçăo enunciativa, constituindo-o, assim, como o sujeito do discurso. Nesta toada, longe de serem práticas neutras, os letramentos sâo práticas sociais ideológicas, pois "servem a propósitos sociais na construçâo e troca de significados, formatam e săo formatados pela cultura, sofrem interferência de posiçôes ideológicas, podendo estas serem explícitas e implícitas, săo dinâmicos à medida que sāo determinados por injunçôes de natureza econômica" (OLIVEIRA, 2010, p.329), bem como tecnológica, política e histórica.

Este conceito de letramento contraria a ideia de linguagem escrita enquanto sistema de códigos, apenas, e de aprendizagem de escrita como desenvolvimento de habilidades cognitivas, com base na qual o modelo tradicional de ensino, definido por Street (1984) como modelo autônomo de letramento, se desenvolveu. Segundo Street (2005), este modelo desconsidera questóes culturais e ideológicas envolvidas nos usos da linguagem escrita, assim como questóes que envolvem as escolhas por detrás deste modelo de ensino, tomando-o como neutro e universal. Conforme o autor, abordagens 
de ensino que fazem uso deste modelo tentam, na verdade, impor conceitos ocidentais de letramento a outras culturas, isto porque, justificando o nome dado pelo pesquisador, o modelo autônomo de letramento deposita grande expectativa no domínio do código linguístico, com base na crença de que a alfabetizaçăo, por si só, autonomamente, levaria a um desenvolvimento cognitivo do aprendiz, o que, por sua vez, implicaria sujeitos mais inteligentes e, por conseguinte, um desenvolvimento socioeconômico da sociedade.

A contestaçâo deste modelo de ensino de leitura e escrita no final do século XX partiu-se, justamente, da constataçâo de que este nâo surgia o efeito esperado, ou seja, mesmo passando anos na escola, submetidos a aulas e mais aulas de redaçâo, os alunos chegavam à universidade e ao mercado de trabalho com "dificuldades" de leitura e produçấo de textos. Além do fato de que năo havia ligaçóes diretas entre alfabetizaçăo e prosperidade econômica. Assim, um novo modelo de ensino de escrita foi proposto pelos NEL. Sob o nome de modelo ideológico de letramento, Street (1984) advogou a favor da necessidade de mudar o antigo modelo de ensino de letramentos de modo a compreender melhor os textos nos seus contextos sociais e históricos.

A negaçăo do modelo autônomo de letramento implica diferenças nâo só na forma como se ensina letramento, mas também na maneira como se avalia o desempenho dos alunos. Street (2012) explica que, ao negar à competência de escrita o caráter de habilidade cognitiva, refuta-se a ideia de que alunos que năo conseguem produzir textos "corretamente" sofrem de limitaçôes e dificuldades de aprendizagem. Além disso, o mito de que a alfabetizaçâo levaria ao progresso social também é negado. Segundo o autor, como năo há um letramento único, autônomo, torna-se impossível se pensar em consequências dos letramentos que sejam as mesmas e intrínsecas a quem o domina. Há diversas práticas de letramentos, cujas consequências têm de ser especificadas em cada contexto.

\section{Abordagens de ensino: Habilidade de Estudo, Socializaçăo Acadêmica e Letramentos Acadêmicos}

Esta nova perspectiva de compreender o letramento despertou o interesse de muitos pesquisadores da linguagem ao redor do mundo e do Brasil, culminando em novas pesquisas desenvolvidas a partir dos NEL. O foco dos trabalhos foi, inicialmente, nos ciclos iniciais do ano escolar, levando certo tempo para que as pesquisas de letramento alcançassem o ensino superior - contexto de interesse do presente trabalho. Mais recentemente, no entanto, as práticas de letramentos do ambiente acadêmico têm sido objeto de grande investigaçáo, no Brasil e no exterior. Em contexto nacional, é relevante mencionar os trabalhos de Komesu (2012), Magalhăes (2012a, 2012b), Tenuta e Oliveira (2012), Corrêa (2011), Oliveira (2009), Oliveira (2010) entre outros.

A esse respeito, Lea e Street (1998) conduziram uma pesquisa a fim de entenderem as abordagens de ensino de letramento desenvolvidas em duas universidades do sul da Inglaterra. Frente a mudanças que vinham ocorrendo no ensino de redaçáo acadêmica no Reino Unido, os autores realizaram um estudo comparativo, investigando as práticas de ensino de uma universidade antiga e de uma nova. Como resultado, os autores verificaram dois tipos de abordagens de ensino: a primeira, que chamaram de 
Habilidades de Estudo, cujos princípios e práticas a aproximam do modelo autônomo de letramento; e a segunda, que nomearam de Socializaçâo Acadêmica.

Esta última, segundo a descriçăo dos autores, move-se em direçăo às práticas defendidas pelos NEL. Fundamentada, também, na escrita/leitura como prática social, compreende que as práticas de letramentos do ensino superior diferem-se daquelas dos anos escolares anteriores, e, por isso, devem ter suas especificidades trabalhadas com os alunos em sala de aula, nâo apenas no que se refere ao léxico específico, mas também no que se refere aos gêneros e sua estrutura textual e retórica. Entretanto, apesar dos avanços que essa abordagem representa em relaçăo à abordagem de Habilidades de Estudos, os autores chamam a atençâo para o fato de que o ensino com base nesta abordagem entende o ambiente acadêmico como uma única comunidade, cujas práticas de letramentos săo semelhantes, independentemente da área. Neste sentido, esta abordagem ainda ignora aspectos cruciais dos letramentos que variam dentre as diferentes áreas de estudo.

Com base nos pressupostos dos NEL, os pesquisadores propuseram uma nova abordagem para o ensino da redaçâo acadêmica. A abordagem de Letramentos Acadêmicos (ACLits) estaria preocupada năo só com gramática, sintaxe e pontuaçăo, ou apenas com vocabulário específico da área, registro acadêmico e formataçăo de textos. Considerando a grande importância de todos esses fatores, ACLits advoga a favor da necessidade de também abordar nas aulas questóes relacionadas à construçáo de sentido, identidade, poder e autoridade dentro de contextos acadêmicos específicos. Conforme Street (2007), esta abordagem acredita que năo só as práticas e os eventos de letramento nos quais os alunos se engajam fora da sala de aula, como também a própria aula e as atividades ali propostas, săo influenciadas por relaçôes de poder, epistemologias de disciplinas específicas e identidades dos alunos e dos professores, por isso, o objetivo da abordagem é facilitar a reflexividade/consciência linguística para a produçâo de textos socialmente reconhecidos.

Por meio da ACLits, busca-se proporcionar um ensino de letramento que permita aos alunos moverem-se de gênero para gênero, mudando seu estilo de escrita a depender do contexto em que estấo, conscientes e capazes de lidar com os significados sociais que cada contexto evoca. Com isso, letrar-se academicamente (ou em outras esferas sociais) significa ter desenvolvidas habilidades para reconhecer os diferentes eventos de letramento, os gêneros que eles demandam, as pessoas ali envolvidas e as diversas relaçôes (sociais e políticas) que os circundam, além de reconhecer como construir textos (em termos de língua, seleçâo de informaçăo e organizaçăo retórica) que respondam às expectativas do público a que se dirigem, ao mesmo tempo em que servem bem ao propósito de quem os escreve. De maneira geral, é possível afirmar, conforme Ivanic (1998), que letrar-se academicamente envolve a construçăo de uma identidade, envolve se tornar certo tipo de pessoa.

\section{Gêneros do discurso, uma perspectiva social}

Entender as práticas de letramentos segundo o modelo ideológico e ensiná-las segundo a ACLits demandam a adoçâo de ferramentas de ensino que nâo negligenciem o caráter dialógico e o potencial transformador do texto. Os gêneros podem servir bem a este propósito. 
O espanto de Candlin já era justificável em 1993 quando questionou o porquê de o termo "gênero" chamar a atençăo de pesquisadores de áreas tăo variadas quanto a de críticos literários, retóricos, sociólogos, cientistas cognitivistas, especialistas em traduçấo automática, linguistas computacionais e analistas do discurso, além de ser do interesse de profissionais de diversas áreas como especialistas em Inglês para Fins Específicos, publicitários e especialistas em comunicaçăo empresarial. Naquela época, há mais de 20 anos, o estudo dos gêneros já tinha grande interesse, e é possível dizer que este interesse vem crescendo, especialmente nas áreas de ciências da linguagem. É preciso lembrar, no entanto, que o termo náo é usado em todas as áreas com a mesma conotaçăo, com os mesmos interesses e com o mesmo embasamento teórico. É preciso, portanto, ao se trabalhar com os gêneros do discurso, localizar devidamente o conceito de gênero que se emprega e os objetivos educacionais/de pesquisa que se tem ao fazer uso de tal conceito.

Gêneros, como os NEL os compreendem, e na perspectiva que usamos neste trabalho, representam padróes discursivos, desenvolvidos socio-historicamente, por meio dos quais indivíduos engajados em determinadas práticas sociais criam sentido. Nas palavras de Hyland (2003, p. 21), săo "modos abstratos e socialmente reconhecidos de usar a linguagem". ${ }^{4}$ Como o autor explica, gêneros sâo construtos sociais porque é o contexto que delimita a criaçăo, o uso e os padrôes textuais dos gêneros. Necessidades de uso da língua em contextos específicos convencionalizam as formas com que os indivíduos se comunicam, e é a partir desse uso convencionalizado que, de acordo com o pesquisador, os indivíduos desenvolvem relacionamentos, estabelecem comunidades e fazem as coisas acontecerem.

Em contexto de ensino de letramentos, é impossível pensar na aprendizagem da leitura e da escrita sem a utilizaçăo de gêneros. Uma vez que toda interaçăo humana se realiza por meio de gêneros, ensinar a comunicaçăo escrita sem abordar os gêneros por meio dos quais ela ocorre é recorrer ao mesmo ensino estruturalista que o modelo autônomo de letramento pressupōe, preparando os alunos para o decodificar de letras em palavras e de palavras em parágrafos. O ensino com gêneros tem o potencial de empoderar os alunos para a manipulaçăo da linguagem em contextos múltiplos, capacitando-os para a elaboraçăo de textos socialmente reconhecidos e que sirvam adequadamente aos seus propósitos. Como afirmam Tenuta e Oliveira (2012), o conhecimento dos gêneros ao mesmo tempo em que é um artefato cultural modelador, é uma força libertadora, pois "insere o falante em uma comunidade linguística, legitimando sua participaçấo nesta" (p. 317). No entanto, para realmente servirem a um propósito de empoderamento dos aprendizes, é preciso trabalhar com os gêneros de forma crítica, ou seja, nâo só promovendo o acesso dos estudantes aos discursos e aos gêneros de poder em contextos específicos, como também, segundo Hyland (2002), abordando maneiras de criticar essas práticas textuais e culturais.

Em contexto acadêmico e para os fins de publicaçăo, o ensino de letramentos por meio de uma abordagem crítica no uso de gêneros pode contribuir significativamente para o sucesso dos alunos em terem seus trabalhos publicados. Entre a escrita,

4 Traduçâo livre. No original: "Genre refers to abstract, socially recognized ways of using language" (HYLAND, 2003, p. 21). 
por parte do pesquisador, e a leitura do público-alvo, há um detalhado processo de análise do texto, por parte da revista/jornal/editora, o qual envolve questóes sociais, institucionais, econômicas, políticas, culturais, históricas, teóricas, metodológicas e, por vezes, pessoais, que năo podem ficar de fora das aulas. Elas săo constitutivas do gênero e precisam ser de conhecimento dos alunos. Năo podem ficar "escondidas".

\section{As dimensóes "escondidas" do letramento e o presumido social dos gêneros do discurso}

O domínio da produçăo de um gênero escrito tem sido difícil de alcançar apenas com aulas de letramento. Essa afirmaçáo pode parecer desanimadora na medida em que desacredita, de certa maneira, a validade das aulas de redaçăo em contexto acadêmico, por exemplo. Mas, o fato é que, por mais dialógica que a abordagem de ensino seja, há dimensōes do gênero que têm permanecido "escondidas" nas aulas (STREET, 2010). Em 1999, Lillis pesquisou um fenômeno chamado "prática institucional do mistério." Segundo a autora, a crença de que as convençôes que regulam a escrita acadêmica sâo transparentes para todos os atuantes da comunidade acadêmica, inclusive para os alunos, leva à omissăo proposital de determinadas convençôes de escrita que os professores julgam já serem de conhecimento dos alunos. No entanto, mais recentemente, Corrêa (2011) afirmou que nem sempre essas omissōes săo propositais e que determinados aspectos do letramento permanecem ocultos devido a um fenômeno que intitulou "presumidos sociais".

Partindo de Bakhtin/Voloshinov, Corrêa leva em consideraçăo o caráter dialógico do discurso para compreender as razôes desses ocultamentos nas aulas de redaçâo. Segundo o autor, eles ocorreriam devido a presumidos sociais que acompanham o uso da linguagem na formulaçấo de enunciados concretos e que atuam como presumidos sociais dos gêneros do discurso. Como explica Komesu (2012), para Voloshinov/ Bakhtin (1926 apud KOMESU, 2012), o discurso verbal é claramente năo autossuficiente, pois é diretamente vinculado à vida, sem a qual perde sua significaçăo. Essa significaçăo depende de um "conjuntamente sabido" e de um "unanimemente avaliado" e, portanto, o enunciado real "traz à cena instância sociocultural mais ampla" (KOMESU, 2012, p. 314), que é o presumido. Assim, é possível relacionar esses ocultamentos nas aulas de letramento aos presumidos sociais dos gêneros, como o fez Corrêa, pois a ilusória sensaçáo dos professores a respeito de um conjuntamente sabido pode levá-los a nâo abordar em sala de aula certas dimensóes dos gêneros que para os alunos podem năo ser tăo óbvias.

Em 2000, Street já havia abordado a questăo das dimensóes "escondidas" do letramento. Em um capítulo de livro em que desafia o gênero e se recusa a escrever conforme os padróes retórico-discursivos esperados, Street traz diversos comentários a respeito do tema "Letramentos Acadêmicos", respondendo a questionamentos e dúvidas (os quais ele náo traz de forma devidamente marcada no texto) de leitores e alunos. Um dos comentários se refere às diversas vozes que temos de lidar ao produzir textos acadêmicos escritos. Segundo o autor, por mais que as aulas de letramentos oferecidas em contexto universitário devessem ajudar os alunos a desenvolverem esta habilidade, uma vez que é uma característica essencial do discurso acadêmico, esta tem sido uma dimensăo dos letramentos que tem permanecido "escondida", sendo motivo de críticas dos alunos. Como consequência desse ocultamento, "a variedade 
torna-se um problema mais do que uma fonte de recursos, especialmente quando diferentes vozes náo săo apenas um 'jogo' para os alunos mas um aspecto central de sua personalidade e identidade" (p. 198). ${ }^{5}$

Retomando o tema das vozes no discurso acadêmico, Street (2010), em uma disciplina de Letramentos na Faculdade de Educaçăo da Universidade da Pensilvânia, ao abordar o gênero artigo de pesquisa, desenvolveu uma atividade de sala de aula, na qual apresentou e discutiu com os alunos uma tabela elaborada por ele com critérios de correçâo de artigos de pesquisa, raramente abordados em sala de aula. O objetivo era trazer ao conhecimento dos alunos algumas dimensôes do gênero que, por ficarem "escondidas", sâo desconsideradas por eles em seu processo de produçấo textual, incorrendo, muitas vezes, na avaliaçăo negativa do artigo. A discussâo com os alunos culminou na reelaboraçáo da tabela, com a adiçăo de outros critérios também relevantes para a avaliaçấo de manuscritos. Dentre eles estavam voz e ponto de vista.

Referente à primeira dimensăo, o autor afirma que é preciso abordar com os alunos a forma como o escritor se posiciona no texto. Diferentemente do que se possa supor, e o que os alunos costumam ser levados a acreditar, a elaboraçấo de um artigo náo pressupóe a apresentaçăo de dados de forma objetiva, como se eles tivessem sido coletados e analisados por si mesmos. Em vez disso, o escritor deve determinar quem ele é como um sujeito situado ao apresentar sua tese. E, referente à segunda dimensăo, o autor explica que, mesmo em textos acadêmicos em que se alega neutralidade, o escrito posiciona-se por meio dos marcadores linguísticos que escolhe. É preciso, portanto, abordar essa questăo com os alunos, para que selecionem os marcadores de forma consciente.

Fischer (2016), interessada em encontrar formas de evitar ou, ao menos, diminuir os casos de dimensôes "escondidas" no ensino da redaçâo acadêmica, realizou um estudo com alunos e professores de um curso de Engenharia de uma universidade portuguesa, no qual avaliou as potencialidades de uma abordagem de ensino baseada em "instruçấo aberta"6 em alcançar tal objetivo. Após um curso de 19 semanas, em que ofereceu um workshop sobre apresentaçăo, outro sobre a escrita do relatório de pesquisa dos discentes, e um terceiro em que realizou sessóes com professores e grupos de alunos a fim de verificar preocupaçóes dos professores e as perspectivas dos alunos sobre sua própria escrita, a pesquisadora chegou à conclusâo de que dimensôes escondidas sâo inevitavelmente constitutivas das práticas de letramentos acadêmicos.

Segundo a pesquisadora, especialistas da área e professores geralmente sabem o que esperam das produçôes dos alunos mas,

a) năo estăo acostumados a articular discursivamente esse conhecimento; b) pode ser que năo esteja muito claro para eles a natureza desse conhecimento [...]; e c) a natureza ideológica das práticas de letramentos - isto é, o fazer de qualquer prática de letramento inevitavelmente envolve questóes fundamentais de

Traduçăo livre. No original: "In the absence of explicitness, variety becomes a problem rather than a resource, especially when different voices are not just a 'game' to the student but a central aspect of their identity and personhood" (STREET, 2000, p. 198).

6 Instruçâo aberta é uma tradução livre para "overt instruction". Segundo a autora, este tipo de instrução envolve a análise de necessidades dos alunos e criaçâo de aulas específicas para atender a essas necessidades. Para maiores informaçôes, ver Henderson \& Exley (2012) e Gee (2002). 
epistemologia (o que conta como conhecimento aqui e agora) e poder (quem pode decidir o que conta como conhecimento) mesmo se essa natureza ideológica do letramento năo for reconhecida.?

Corroboramos dessa afirmaçáo e acreditamos que, por mais "transparente" que seja a abordagem de ensino de letramentos que o professor adote em sala, procurando abordar qualquer dimensăo que se possa pensar de um determinado gênero para uma determinada área, como o artigo de pesquisa para Ciência da Computaçăo, por exemplo, ainda assim, a produçấo de exemplares do gênero e a aceitaçăo do manuscrito para publicaçáo pode ser um processo obscuro e incerto. Isto porque, este processo envolve diversas pessoas e, portanto, diversas visôes de mundo, de língua, de texto, de discurso acadêmico etc., impossíveis de se prever e de se abordar em sala de aula.

A partir disso, é preciso que jornais e revistas especialistas, para onde destinam a maioria dos artigos de pesquisa produzidos em contexto acadêmico, devem também prezar pela "transparência" e incluir nas diretrizes para autores o maior número possível de informaçôes a respeito do que, para o periódico, se consiste um artigo de pesquisa. Estas informaçôes ajudam náo só os autores a produzirem um texto conforme as regras sociais daquele evento, como também os pareceristas convidados a avaliarem os manuscritos tendo em mente os mesmos critérios.

A seguir, descreveremos com detalhes o processo de análise, sob uma perspectiva etnográfica discursiva (CORRÊA, 2011), das diretrizes para autores dos periódicos em Ciência da Computaçâo referente às dimensôes que permanecem "escondidas" e que podem atrapalhar os autores a terem seus trabalhos aceitos para publicaçâo.

\section{A PERSPECTIVA ETNOGRÁFICA DISCURSIVA NA ANÁLISE DOS PERIÓDICOS}

O presente trabalho tem por objetivo apresentar uma análise realizada em periódicos da área de Ciência da Computaçăo a fim de evidenciar possíveis dimensôes escondidas nas instruçôes dadas aos autores para a elaboraçâo de artigos de pesquisa a serem submetidos. A perspectiva de análise baseia-se em Corrêa (2011) e, depositando um foco maior sobre os conceitos de língua, texto e gênero que embasam as práticas de letramento das revistas, verifica como possíveis presumidos sociais do gênero em questâo, fundamentados por esses mesmos conceitos, podem causar o ocultamento de orientaçóes relevantes aos autores nas diretrizes.

Nesta sessăo serăo apresentados os critérios de seleçăo dos periódicos, uma breve descriçăo de cada um deles e a perspectiva etnográfica discursiva de investigaçăo.

\section{Sobre o material de estudo}

Ao todo, constam no corpus da pesquisa seis periódicos da grande área de Ciência da Computaçâo (doravante CC), abrangendo três das quatro subáreas em que CC se

Traduçáo livre: No original: "a) they are not used to articulating such discursive knowledge; b) it may be that it is far from clear what the nature of the knowledge expected is [...] and c) the ideological nature of literacy practices - that is, the doing of any literacy practice inevitably involves fundamental issues of epistemology (what counts as knowledge here now) and power (who can claim what counts as knowledge) even though this ideological nature of literacy is not acknowledged" (FISCHER, 2016, p. 83). 
divide: Teoria da Computaçấo, Metodologia e Técnicas da Computaçăo, e Sistemas de Computaçâo. ${ }^{8} \mathrm{O}$ quadro (1) apresenta o nome de cada um dos periódicos e sua(s) área(s) de concentraçăo.

\section{Quadro 1: Área(s) de concentração de cada revista constituinte do corpus da pesquisa}

\begin{tabular}{c|c}
\hline Periódico & Área(s) de concentração \\
\hline Transactions on Intelligent Systems and Technology (TIST) & $\begin{array}{c}\text { Teoria da Computação e Inteligência Artificial } \\
\text { Automática }\end{array}$ \\
$\begin{array}{c}\text { Engenharia de Controle e de Sistemas, Engenharia } \\
\text { Elétrica e Eletrônica }\end{array}$ \\
\hline Bioinformatics & $\begin{array}{c}\text { Matemática Aplicada, Bioquímica, Ciência da } \\
\text { Computação Aplicada, Biologia Molecular, Matemática }\end{array}$ \\
\hline The Journal of Statistical Software (JSS) & $\begin{array}{c}\text { Software, Estatística e Probabilidade, Estatística, } \\
\text { Probabilidade e Incerteza }\end{array}$ \\
\hline Journal of Medical Internet Research (JMIR) & Informática para a saúde \\
\hline Machine Learning & Inteligência Artificial e Software
\end{tabular}

Fonte: Scimago Journal \& Country Rank (SJR)

Os critérios de seleçâo dos periódicos obedeceram a um único princípio: ser de grande interesse para graduandos e pós-graduandos. Para atender a esse princípio, portanto, o primeiro critério prezava pelo fator de impacto da revista. Em CC, este é o primeiro critério de avaliaçấo de um periódico. Assim, para ser analisado, o periódico deveria apresentar avaliaçăo Q1 pelo Scimago Journal \& Country Rank (SJR). Este critério, embora relevante, resultou em centenas de periódicos passíveis de serem analisados. A fim de reduzir as possibilidades, o segundo critério prezava por uma alta avaliaçăo por instituiçóes e órgăos brasileiros; assim, buscamos por periódicos que, além de terem uma avaliaçấo Q1, pelo SJR, também possuem avaliaçâo A1, pela CAPES.

Quarenta e um periódicos atendiam aos dois primeiros critérios. Uma breve análise em cada um deles, investigando a relaçăo conteúdo das diretrizes $\mathrm{X}$ editora, revelou que revistas publicadas pela mesma editora continham as mesmas informaçóes. Assim, reduzimos a lista a apenas uma revista de cada editora, restando, no final, onze periódicos a serem analisados. Uma investigaçâo mais atenta, buscando pela titulaçăo mínima para autores, entretanto, revelou que nenhuma continha esta informaçăo. Considerando que o interesse maior desta pesquisa está nos universitários, seria indispensável que a revista aceitasse publicaçâo de năo-doutores. Assim, um e-mail foi enviado aos editores de cada revista, questionando a esse respeito.

Apenas seis revistas responderam aos e-mails, informando que qualquer autor que escrever trabalhos inéditos e relevantes para a área de interesse da revista sâo bem-vindos a submeterem seus textos, inclusive universitários. Alguns editores informaram, inclusive, que năo há se quer um questionamento sobre a titulaçâo dos autores. Essas seis revistas constituem o corpus deste trabalho.

8 Nâo há um consenso quanto à quantidade, tampouco aos campos de interesse, em que se divide a grande área de CC. Para este estudo, adotamos a descriçăo das três maiores agências de fomento brasileiras, cuja divisăo de subáreas e campos de interesse săo correspondentes. A saber: FAPESP, CAPES e CNPq. 


\section{Sobre as revistas}

Todas as revistas selecionadas possuem um sistema de submissăo online e, portanto, diretrizes para autores facilmente acessíveis. Ademais, é recorrente encontrar no site das revistas informaçôes referentes ao escopo da revista; direitos de autoria; política de privacidade; política de acesso aos conteúdos; políticas e valores para filiaçâo, submissăo e publicaçâo de manuscritos; ética e boas práticas acadêmicas; artigos mais citados e artigos mais baixados; volume atual e volumes anteriores; instituiçōes parceiras e quadro editorial. Ademais, todas possuem links de acesso às perguntas mais frequentes, ao fale conosco, ao sistema para submeter o artigo e ajuda para ediçăo e traduçăo de textos para o inglês, uma vez que esta é a língua de submissão dos artigos.

Algumas revistas, no entanto, possuem uma gama maior de informaçôes disponíveis a autores, leitores, pareceristas e editores, como é o caso das revistas cuja editora é renomada na área e é responsável por um grande número de periódicos. A revista TIST é um periódico norte americano, publicado pela ACM (Association for Computing Machinery) - uma associaçâo com mais de 60 anos de história, dedicada à publicaçăo de resultados de pesquisas em CC, com o objetivo de dar suporte às necessidades da comunidade de computaçáo (pesquisadores, professores, alunos e profissionais). O site da revista trata-se de uma aba no endereço eletrônico da ACM e todas as informaçŏes săo dispostas com links que levam a textos produzidos pela ACM para o funcionamento de todos os periódicos. Trata-se, portanto, de um site com muita informaçâo para autores, leitores, pareceristas e editores. Esta é uma das poucas revistas que oferece diretrizes de avaliaçăo de manuscritos para pareceristas, além de critérios de seleçâo de editores.

Localizada no Reino Unido, a revista Automática é publicada por outra grande editora, a Elsevier. Com mais de 3.000 periódicos, Elsevier também é responsável pelas informaçōes e instruçōes encontradas em cada um deles. Além de informaçôes e orientaçóes a todos os envolvidos no processo de submissăo, avaliaçăo, editoraçăo e publicaçâo dos artigos, Elsevier também disponibiliza materiais em texto e vídeo, na forma de palestras, cursos online e artigos acadêmicos, destinados a ajudar autores no processo de elaboraçâo dos textos. Há conteúdo destinado a desenvolver habilidades de escrita de artigos, a promover a compreensăo sobre a importância do processo de revisăo de pares e como lidar com o feedback dos pareceristas, a instruir os autores sobre como deixar os artigos interessantes para alcançar o maior número possível de leitores, e notáveis, de forma a conseguir apoio financeiro para a pesquisa, e sobre como agir eticamente no ambiente acadêmico e no processo de publicaçăo. Esses materiais, infelizmente, năo foram analisados nesta pesquisa, pois năo se encontram presentes, nem em forma de links de acesso, na seçâo de diretrizes para autores, foco de análise desta investigaçâo.

Também Britânica, a revista Bioinformatics é publicada pela BioMed Central e possui todo o seu conteúdo livre para o acesso, assim como todos os periódicos publicados por esta editora. Em consonância às revistas previamente descritas, todas as informaçôes da revista estâo ligadas à editora e estas se limitam a instruçōes, diretrizes e informaçōes a autores e leitores, contendo pouquíssimo conteúdo destinado a pareceristas e/ou editores. Machine Learning é a última revista cujo funcionamento é padronizado aos interesses da editora. Localizada na Holanda e publicada pela Springer, 
esta revista possui um fator de impacto de 2.404 pelo SJR, e um processo de análise de periódicos que leva cerca de 90 dias da submissáo à primeira publicaçăo online.

JSS e JMIR, norte-americana e canadense respectivamente, săo publicadas pelas editoras FOAS (Foundation of Open Access Statistics), a qual trabalha única e exclusivamente com a JSS, e JMIR Publication, que possui outros 16 periódicos, todos interessados em medicina e computaçăo. A navegaçăo nesses sites é mais fácil, por nâo haver tantos links direcionando o usuário a novas páginas no endereço eletrônico das editoras. No entanto, é possível que, devido à quantidade de informaçôes para autores, leitores, pareceristas e editores ser reduzida, haja vários casos de dimensôes "escondidas", principalmente relacionadas aos critérios de avaliaçăo dos manuscritos.

\section{Sobre a perspectiva de análise}

A presente pesquisa, que se caracteriza como um estudo de caso de caráter qualitativo-interpretativista, teve como procedimento de análise de dados a perspectiva etnográfica discursiva (CORRÊA, 2011). Uma vez que a investigaçăo tem como material de estudo textos produzidos pelas revistas especialistas aos possíveis autores, com o objetivo de orientar a elaboraçáo e a submissáo de seus manuscritos, a análise baseou-se nos textos apenas, e, portanto, năo contou com a participaçăo dos sujeitos que produziram tais textos. Esta escolha metodológica justifica-se tanto pelos princípios teóricos que embasam a pesquisa, quanto pelos objetivos por ela pretendidos.

Esta perspectiva trata-se de uma tentativa de Corrêa em aproximar a perspectiva etnográfica, tâo cara aos NEL, à linguístico-discursiva. Tomando os dados etnográficos da produçâo dos textos como fatos do discurso simultâneos à formulaçaáo linguística, e nâo como dados que refletiriam uma determinaçăo prévia ligada ao contexto situacional, a perspectiva etnográfica discursiva serve aos objetivos desta pesquisa na medida em que nos permite verificar as intertextualidades e as interdiscursividades presentes nos textos, as quais podem revelar os conceitos de língua, texto e gênero que fundamentam as diretrizes de produçâo textual destinada aos autores das revistas.

Komesu (2013) explica que esta perspectiva metodológica permite, pois, ao observar práticas discursivas registradas em textos, reconhecer "a complexidade de relaçóes concretas que implicam interpelaçôes e coerçōes nâo ditas que năo sâo, necessariamente, percebidas como tais pelos sujeitos" (p. 314). Investigar possíveis dimensóes escondidas nas diretrizes para autores das revistas significa levar em consideraçâo possíveis presumidos sociais do gênero artigo de pesquisa, os quais podem levar os responsáveis pela revista a omitirem informaçôes relacionadas à elaboraçăo e circulaçâo de tal gênero, consideradas já sabidas pelos autores. Nem sempre esses ocultamentos sâo intencionais, como afirma Corrêa, uma vez que os presumidos sociais sâo da ordem do inconsciente. Assim, a análise dos textos, sob a perspectiva aqui adotada, pode revelar mais sobre esses presumidos do que se captaria por meio de entrevistas com os editores das revistas.

O foco de análise da presente pesquisa será as informaçōes a respeito dos direitos dos autores e políticas de autoria, bem como as orientaçôes para a elaboraçâo de manuscritos e os processos de submissăo dos manuscritos, em busca de evidenciar os conceitos de língua, texto e gênero que fundamentam as práticas de letramento da revista. Esses conceitos, apreendidos e desenvolvidos pelo sujeito em sociedade, implicam 
năo só a produçăo de textos por parte das revistas, mas também as orientaçôes para elaboraçấo de manuscritos oferecidas por estas aos autores. $\mathrm{O}$ reconhecimento desses conceitos, portanto, possibilitará entender possíveis dimensôes "escondidas" do letramento, presentes nas diretrizes para autores, relacionando-as a presumidos sociais do gênero artigo de pesquisa, que săo, por sua vez, também embasados por tais conceitos.

\section{AS DIMENSÕES "ESCONDIDAS" DO LETRAMENTO ACADÊMICO NAS DIRETRIZES PARA AUTORES DE PERIÓDICOS EM CIÊNCIA DA COMPUTAÇÃO}

Nesta sessăo apresentaremos uma descriçăo das diretrizes para autores das seis revistas especializadas em CC. De maneira geral, o conteúdo dos textos será apresentado, seguido por uma análise etnográfica discursiva que busca pelos conceitos de língua, texto e gênero que fundamentam as práticas de letramento das revistas. Concomitantemente a isso, serăo evidenciadas as dimensôes "escondidas" do letramento encontradas ao longo dos textos analisados, as quais seráo analisadas e relacionadas a presumidos sociais do gênero artigo de pesquisa, como tentativa de explicar, etnograficamente, tais ocultamentos.

\section{Localizaçăo, formato e conteúdo dos textos}

Em todas as revistas, as diretrizes para autores săo facilmente encontradas já na primeira página do endereço eletrônico. Nas revistas TIST, JMIR e JSS elas aparecem com o nome de "Author guidelines"; na Automática, com o nome de "Guide for Authors"; Bioinformatics utiliza o nome de "Submission guidelines"; e Machine Learning identifica as diretrizes como "Instructions for authors". Essa multiplicidade de nomes na identificaçăo de textos dessa natureza já evidencia, de antemăo, uma falta de padrâo na produçăo desse gênero9.

O formato dos textos comprova esta afirmaçấo. TIST, Automática e JMIR apresentam o texto divido em tópicos, nos quais há uma breve explicaçăo de cada tópico, com links variados que levam a outras páginas (das editoras ACM, Elsevier e JMIR, respectivamente), onde se pode encontrar informaçóes mais completas. Bioinformatics apresenta apenas os tópicos e os links, ou seja, para o acesso a qualquer uma das informaçôes de cada tópico é preciso acessar o link, o qual direciona o leitor ao texto completo presente no endereço eletrônico da editora (BMC). Machine Learning, por sua vez, apresenta todas as informaçôes neste mesmo texto, o qual é também divido em tópicos, e, portanto, nâo há links de acesso a outras páginas. JSS, diferenciandose de todas as revistas, apresenta as informaçôes como respostas às perguntas mais frequentes relacionadas à submissăo de artigos. Também năo há links de redirecionamento em nenhum lugar do texto.

O conteúdo do texto também diverge de revista para revista. Foram verificados apenas quatro assuntos recorrentes em todos os textos: direitos dos autores, políticas

9 Embora nâo tenhamos encontrado estudos que classifiquem "diretrizes para autores" como um gênero discursivo, o fato de se tratar de uma prática social, com claros objetivos comunicativos e utilizado por sujeitos com específicos papéis sociais em sua comunidade, leva-nos a compreendê-lo como um gênero acadêmico-científico. 
de autoria, estilo dos textos10 e link para o endereço eletrônico por onde se realiza a submissáo dos manuscritos. A maioria dos textos (4) traz informaçóes a respeito do escopo da revista (facilmente encontrado também na página inicial do endereço eletrônico de todos os periódicos); categorias de submissăo, ou seja, os gêneros por meio dos quais os autores podem compartilhar o resultado de suas investidas acadêmicocientíficas; referências e citaçóes; imagens e tabelas; e serviços de traduçăo e ediçâo dos manuscritos. Metade dos textos (3) aborda a quantidade de páginas que cada exemplar de cada gênero deve conter; o tempo estimado para análise e publicaçăo dos manuscritos; valores cobrados para inscriçấo no periódico, submissâo, publicaçăo e/ ou acesso aos textos publicados; termos e condiçóes para submissăo; informaçóes a respeito de abreviaçôes, palavras-chave, artigos já publicados ou submetidos a outros periódicos, página do título, línguas para submissâo, material suplementar; e link de contato para tirar dúvidas sobre elaboraçấo e submissáo dos textos.

Contribuindo ainda mais para a afirmaçâo de que nâo há um padrâo para a elaboraçăo de textos do gênero, ainda a respeito do conteúdo dos textos das revistas analisadas, foi possível verificar que, em alguns textos (2), há informaçōes a respeito da estrutura que artigos devem ter, ou seja, as diferentes seçōes do artigo, bem como subseçôes; de como estruturar resumos e agradecimentos; sobre conflitos de interesse, processo editorial e de avaliaçăo dos manuscritos; de como proceder depois do aceite; sobre o envio e leitura do corpus da pesquisa; quantas cópias impressas os autores têm direito; transferência de manuscrito a outra revista cujo escopo se encaixa melhor à temática do artigo; checklist para submissáo; e sobre política de privacidade. Ademais, TIST traz links para o acesso dos autores a representaçóes dos autores, ou seja, a imagens que a revista gostaria que os autores tivessem do periódico; ao corpo editorial; à política de publicaçăo; e informaçôes a respeito dos tipos de avaliaçăo a que os manuscritos serấo submetidos, e sobre como promover a leitura do artigo. Automática aborda a submissáo de audioslides junto ao manuscrito, biografia do autor e descarte de material. JMIR inclui no texto informaçōes sobre cada parte do artigo, assim, também apresenta diretrizes para a formataçấo da introduçăo, da metodologia, dos resultados, da discussâo e dos apêndices; além disso, explica sobre o processo de nominaçấo de pareceristas por parte dos autores e quais os direitos da revista sobre os manuscritos publicados. Bioinformatics é a única revista que traz nas diretrizes para autores links de acesso para as políticas editorias e de avaliaçâo por pares. JSS, com uma linguagem muito técnica, e abordando conteúdos também estritamente técnicos, destaca-se por disponibilizar informaçôes sobre o uso de letras maiúsculas no título e no corpo do texto. E, por fim, Machine Learning é a única revista que traz informaçóes a respeito das notas de rodapé, necessidade de autorizaçáo para o uso de imagens de autoria de outrem, responsabilidades éticas dos autores e transferência de direitos autorais.

Uma breve análise de outras páginas presentes nos sites das revistas e das editoras permite afirmar que a maioria de todas essas informaçôes sâo disponibilizadas por todas as revistas, em seçōes nomeadas como "editores", "pareceristas", "arquivo" etc. Entretanto, como o objeto de estudo desta pesquisa é as diretrizes para autores, a análise, conduzida sob a perspectiva etnográfica discursiva, limitou-se ao conteúdo

10 Estilo refere-se ao formato eletrônico do texto: se em LaTeX, MSWord ou RTF; bem como orientaçôes para formataçăo dos textos em cada formato eletrônico. 
recorrente em todos os textos analisados, a saber: direitos dos autores, política de autoria, estilo dos textos e processo de submissăo.

\section{Os conceitos de Língua, Texto e Gênero que fundamentam as práticas de letramento das revistas}

Todas as revistas analisadas apresentam grande preocupaçáo com a formataçâo do arquivo a ser submetido, mais do que com estrutura, registro, conteúdo ou discursos neles vinculados. Essa afirmaçâo se fundamenta a partir da verificaçâo de que todas elas disponibilizam arquivos com informaçōes a respeito de programas cujos formatos săo aceitáveis, mas nem todas disponibilizam informaçóes sobre estrutura e conteúdo, e nenhuma aborda registro e discurso.

Esses arquivos trazem conjuntos de comandos de alto nível usados na formataçăo de documentos apresentados em formato LaTeX, Word e RTF. Como pesquisadores em linguística, nossa experiência pessoal náo nos foi suficiente para entender esses arquivos, assim, precisamos contar com a ajuda de um consultor, ${ }^{11}$ especialista na área, para compreender o propósito social desses textos. Segundo o consultor, nesses textos săo disponibilizados códigos computacionais a serem digitados no programa de forma com que a formataçăo do documento seja feita automaticamente. Assim, há códigos para cada parte do artigo, bem como para alguns conteúdos, como folha do título, resumo, tabelas etc. Dispondo desses códigos, o autor entra no programa, por exemplo, o LaTeX, e digita o texto junto aos códigos de comando, ao final, gera o arquivo em PDF para leitura, o qual já vem formatado de acordo com as especificaçôes da revista. A imagem 1 apresenta um trecho do texto de um dos arquivos de uma das revistas analisadas.

Esse foco na linguagem computacional para a formataçăo dos textos permite inferir o conceito de texto que fundamenta as práticas de letramento da revista. A falta de informaçóes que abordem os temas discurso e registro, aliada à intensa preocupaçáo com espaçamento entre linhas e parágrafos, tipo de fonte e tamanho de letra, estilo de citaçăo e referência revela uma visăo estrutural de texto escrito, em que forma e estilo săo primordiais e, por vezes, suficientes para gerar significados nos textos, mais do que funçăo e conteúdo.

Essas informaçôes, que nâo sâo disponibilizadas pelas revistas, aparecem como dimensóes "escondidas" do letramento e que podem prejudicar os autores no processo de avaliaçăo de seus manuscritos. Isso porque, embora năo explicitados nas diretrizes para autores, sáo cobrados por pareceristas e editores das revistas. 0 editor da revista Bioinformatics, em conversa por e-mail, nos informou que um dos motivos pelos quais um manuscrito pode ser rejeitado pela revista é por năo seguir padrôes compartilhados pela comunidade, relevantes para a área de pesquisa. Esses padróes, que se referem a práticas de pesquisa, implicam padrōes de compartilhamento dessas práticas os quais năo săo abordados nas diretrizes para autores, mas, segundo o editor, săo cobrados pelos pareceristas e editores.

11 Renan Guilherme Nespolo, mestre na área pela Universidade Estadual Paulista - Júlio de Mesquita Filho. 
Imagem 1 - Um trecho do Guia de Estilo LaTeX

\section{THE TITLE PAGE}

\subsection{The Title, Author(s), and Abstract}

Following order is mandatory to generate a correct title page:

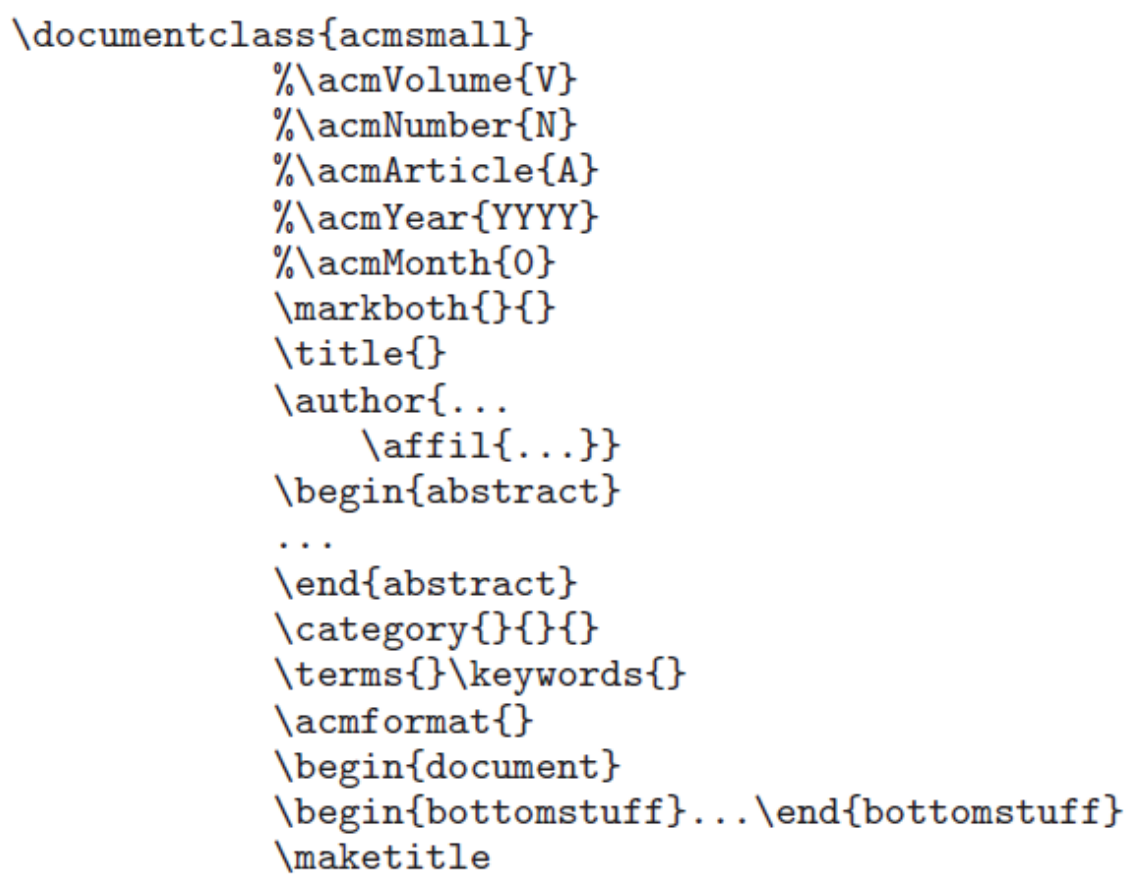

Fonte: Association for Computing Machinery (ACM). Disponível em: http://www.acm.org/ publications/acm-latex-style-guide

É possível afirmar que esse ocultamento aconteça devido a um presumido social de que, uma vez que o autor realizou a pesquisa em determinada área, este comunga dos padróes de pesquisa da comunidade e, portanto, está ciente dos padróes de compartilhamento dessas pesquisas. Entretanto, pesquisadores novatos podem ainda estar sendo iniciados nesses padróes de pesquisa e desconhecerem parcial ou totalmente os padróes de compartilhamento de pesquisas, sendo importante, portanto, que as revistas abordem essa problemática, de modo a auxiliar esses pesquisadores a reconhecerem e a reproduzirem as práticas de pesquisas de sua área de atuaçăo que lhes sâo cobradas. Como sugere Street (2010), é preciso tornar explícito alguns conceitos já reconhecidos e utilizados por pesquisadores da área na produçăo de artigo, pois podem náo ser tăo óbvios para alunos e pesquisadores iniciantes.

A análise desses arquivos com informaçôes para a formataçăo dos textos, junto à análise de informaçóes referentes aos tipos de contribuiçăo de que os autores podem fazer às revistas, presentes nas diretrizes para autores de algumas revistas e em textos de outros "gêneros" de outras revistas, permitem ainda inferir outro conceito fundamental que embasa as práticas de letramento dos periódicos - o de gênero. Duas das revistas (TIST e Machine Learning) aceitam apenas artigos de pesquisa, justificando, portanto, a existência de apenas um tipo de arquivo para 
formataçăo, no entanto, JMIR, Automática e JSS trabalham com a publicaçăo de mais de um gênero, tais como tutoriais, resenhas de produtos, cartas ao editor, resenhas de livros, resenhas de softwares, mas tendem a apresentar apenas um arquivo com comandos para a formataçăo de manuscritos, com exceçấo da JSS, que também apresenta comandos para a formataçăo de resenhas de livros e softwares. Bioinformatics é a única revista que apresenta regras de formataçâo para cada um dos quatro gêneros com que trabalha.

Embora esses arquivos sejam em grande parte compostos por comandos computacionais para a formataçăo de textos, eles trazem algumas informaçôes sobre conteúdo, especialmente no que se refere à estrutura do artigo de pesquisa, isto é, as partes que este deve conter e a ordem em que devem aparecer. Neste caso, é de se estranhar que as revistas JMIR, Automática e JSS ofereçam apenas um arquivo para formataçăo e estruturaçăo de textos, referente à elaboraçăo de artigos de pesquisa, sendo que estas aceitam também outros gêneros para submissâo e publicaçăo. A partir deste estranhamento, analisamos a forma como as revistas definem os diferentes gêneros com os quais trabalham, a fim de entender o porquê deste comportamento.

JMIR, em um texto intitulado "Instructions for Authors", cujo link se encontra nas diretrizes para autores, informa que aceita onze "tipos de contribuiçōes", a saber: artigos originais, artigos reduzidos, pontos de vista, artigos consensuais, resenhas, tutoriais, relatos de caso, propostas, comentários, resenhas de livros, resenhas de software, protocolos de pesquisa, propostas de subsídios e carta ao editor. ${ }^{12}$ Desses tipos de contribuiçôes, é possível identificar ao menos seis gêneros: artigo de pesquisa, resenha, comentário, protocolo de pesquisa, proposta de subsídio e carta; cujos propósitos comunicativos sâo distintamente diferentes e, portanto, devam apresentar uma estrutura composicional e retórica e conteúdo específicos. No entanto, a revista parece entender cada um desses tipos de contribuiçóes como o mesmo gênero, já que classifica todos sob o mesmo termo: "paper", ou seja, trabalho acadêmico. Fundamentando esta informaçăo, ao apresentar os tipos de contribuiçôes, a revista o faz em forma de lista e nenhuma informaçâo a respeito de seu propósito social ou conteúdo sâo dadas, apenas a quantidade de palavras esperadas em um artigo reduzido (1.500). Ademais, uma informaçăo geral sobre conteúdo e estrutura dos papers é dada ao final da lista. Veja no quadro 2.

\section{Quadro 2: Orientações gerais sobre a estrutura de manuscritos da revista JMIR ${ }^{13}$}

[...] todos os trabalhos devem conter as seguintes seções: Resumo [...], Palavras-chave, Corpo do texto (veja abaixo para artigos originais), Agradecimentos, Conflitos de Interesse, Referências.

Fonte: Revista JMIR. Disponível em: http://www.jmir.org/content/author-instructions\#Format

12 Traduçāo livre. No original: "original papers, short papers, viewpoints, consensus papers, reviews, tutorials, case reports, policy papers, commentaries, book/software reviews, research protocols, grant proposals and letter to the editor".

13 [...] all papers must contain the following sections: Abstract [...], Keywords, Main article body (see below for original articles), Acknowledgements, Conflicts of Interest, References. 
Uma informaçăo semelhante é dada pela revista Automática. Ao também listas os tipos de contribuiçôes que os autores podem submeter à revista, a saber: artigos teóricos, artigos de pesquisa, artigos reduzidos, comunicaçóes técnicas e itens de correspondência ${ }^{14}$ (em que se enquadram cartas ao editor e comentários sobre artigos publicados pela revista), o periódico informa que todos os manuscritos devem seguir a seguinte ordem: título, autores, afiliaçóes, resumo, palavras-chave, texto principal, agradecimentos, apêndice e referências. Como a JMIR, portanto, a revista Automática prevê a mesma estrutura composicional para todos os textos de todos os gêneros, mesmo reconhecendo que cada um deles tem um propósito social diferente. Na frente de cada tipo de contribuiçăo, é possível encontrar uma breve explicaçăo sobre os objetivos comunicativos de textos do gênero, junto à quantidade máxima de páginas e de palavras esperadas. Artigos de pesquisa, por exemplo, săo definidos como "discussóes detalhadas envolvendo pesquisas, aplicaçōes ou desenvolvimentos novos,"15 normalmente até 10 páginas ou 10.000 palavras; e comunicaçōes técnicas como "novas ideias úteis e pequenos comentários pertinentes de natureza técnica," ${ }^{16}$ normalmente até quatro páginas ou 4.000 palavras.

O fato de existir apenas um arquivo para a formataçấo de manuscritos a serem submetidos, mesmo existindo mais de um gênero com o qual as revistas trabalham, somado à orientaçấo feita por cada revista referente ao conteúdo dos manuscritos, frisando que todos devem seguir a mesma estrutura, revelam uma visăo de gênero próximo à abordagem de ensino de letramentos, definida por Lea \& Street (1998) como socializaçâo acadêmica. Segundo esta abordagem, é reconhecido diferenças sociais nos usos de textos escritos nas diferentes esferas de atividade humana, assim, na esfera acadêmica, os textos acadêmicos săo usados com propósitos comunicativos específicos por pessoas dessa comunidade e, portanto, possuem uma configuraçáo distinta de textos usados no comércio, por exemplo. No entanto, este modelo ainda ignora diferenças existentes entre os diferentes gêneros acadêmicos. Diferenças de propósitos comunicativos, contexto de produçâo, questôes políticas, papéis sociais dos envolvidos etc. que culminam em diferenças linguístico-textuais. Assim, este modelo, tal qual fazem as revistas, acredita que as especificidades do discurso acadêmico săo transferíveis de gênero para gênero.

Esta visăo de gênero, como estrutura linguístico-textual das diferentes comunidades de prática, é comungado, portanto, pela revista JSS, que também possui apenas dois textos diferentes para a formataçăo de cinco gêneros com os quais trabalham; e pela TIST que, em seu texto para formataçăo, informa que a digitaçăo do corpo do texto tende a ser feita como o é em textos comuns (nâo acadêmicos), com exceçâo de listas, teoremas, algoritmos e programas. Esta informaçăo revela, portanto, a diferenciaçâo e, por conseguinte, generalizaçăo, dos gêneros acadêmicos, em oposiçăo a textos de gêneros que circulam em outras esferas sociais.

\footnotetext{
14 Traduçáo livre. No original: "survey papers, papers, brief papers, technical communiqués, correspondence items".

15 Traduçăo livre. No original: "Detailed discussion involving new research, applications or developments".

16 Traduçăo livre. No original: "New useful ideas and brief pertinent comments of a technical nature".
} 
Apesar desta visăo de gênero dificultar o trabalho de autores que desejam submeter a essas revistas textos correspondentes aos variados gêneros com quais elas trabalham, é preciso frisar que, para a submissâo de artigos de pesquisa, que é o foco de interesse da presente pesquisa, os autores encontram uma vantagem, já que os arquivos de formataçâo săo para este gênero. Entretanto, ainda assim é possível encontrar dimensôes "escondidas" dos letramentos nesses guias de formataçăo (como săo chamados). Ainda que se dediquem apenas à formataçăo e à apresentaçăo do conteúdo dos manuscritos, a parte mais importante do texto, chamada de "main article body" pela JMIR e "main text" pela Automatica, năo é, por esta última, detalhadamente descrita. O que JMIR descreve como "main article body" inclui introduçáo, método/metodologia, resultados e discussāo, seçôes em que os diferentes estágios da pesquisa sâo narrados e cujo conteúdo implica diretamente o aceite ou a recusa do trabalho. Segundo informaçōes do editor da revista Bioinformatics, o que sua revista busca nos artigos sāo estudos cientificamente válidos, o que inclui perguntas de pesquisa cientificamente interessantes e o uso de métodos de coleta e análise de dados apropriados. Essa informaçăo, no entanto, como visto, năo esta disponível nas diretrizes da revistas em questâo e em nenhuma das outras analisadas.

Este ocultamento pode também ser explicado com base em presumidos sociais do gênero. Uma vez que artigos de pesquisa relatam todos os estágios da pesquisa, é de se esperar que se coloque na introduçâo as perguntas de pesquisa, seguida da metodologia de coleta de dados e por fim a análise e discussâo dos mesmos. No entanto, como argumenta Fischer (2016), comumente há lacunas na compreensăo e expectativas de escritores experientes e novatos (professores e alunos, no caso da pesquisa da autora, respectivamente) sobre as formas e normas que governam os gêneros. Assim, ainda que pareça óbvio, é interessante que as revistas deixem explícitas essas dimensóes do letramento, năo só no que diz respeito à formataçăo, estrutura e conteúdo dos textos, como também no que se refere aos propósitos sociais e aos discursos esperados pelas revistas, de modo a facilitar a inserçâo dos jovens pesquisadores na comunicaçấo acadêmico-científica.

Finalizando a análise, descreveremos como as informaçōes referentes às políticas de autoria, aos direitos dos autores e às citaçóes e referências nos permitiram inferir o conceito de língua escrita que fundamenta as práticas de letramento das revistas. De uma maneira geral, é possível afirmar que os periódicos fundamentam suas práticas em um conceito de língua escrita como prática social, uma vez que se classificam como um instrumento mediador da comunicaçăo acadêmico-científica. Ademais, todas as revistas dedicam-se a discutir os direitos dos autores e as políticas de autoria, especialmente sobre os processos de compartilhamento e citaçâo dos trabalhos publicados pelas e nas revistas, evidenciando uma consciência sobre o caráter social da escrita. O problema é que, mesmo apoiadas em uma perspectiva social de língua escrita, a maioria das revistas limitam suas orientaçôes aos autores sobre a elaboraçáo de citaçăo e referências a aspectos formais, ou seja, à formataçăo do texto.

Como exceçăo, a revista Bioinformatics apresenta um link nas diretrizes para autores que leva às políticas editoriais da revista onde se encontra um texto sobre como agir com relaçāo a citaçôes. Embora seja um texto prescritivo, que, na forma imperativa, informa o que o autor deve e năo deve fazer, sem problematizar as questôes, esta revista 
avança um pouco mais na descriçăo das dimensóes dos letramentos que espera que os autores sigam, evitando tantos ocultamentos, como acontece nos outros periódicos. Nesta página da revista, é possível encontrar as orientaçōes dispostas no quadro 3.

\section{Quadro 3: Orientações da revista Bioinformatics para a utilização de citações nos manuscritos ${ }^{17}$}

- Qualquer sentença no texto que se baseie em fontes externas de informaçăo (isto é, que náo se baseie em novas ideias dos próprios autores ou em achados e conhecimentos do senso comum) deve ser seguida por citaçăo;

- Autores devem evitar citar derivaçóes de trabalhos originais. Por exemplo, devem citar o trabalho original ao invés de um artigo de revisâo que cite o trabalho original;

- Autores devem certificar-se de que as citaçôes estâo corretas (isto é, devem certificar-se de que a citaçâo dá suporte à sentença escrita no manuscrito e năo devem representar de maneira equivocada outro trabalho, citando-o em casos em que a citaçáo náo dá suporte ao argumento que os autores desejam desenvolver);

- Autores náo devem citar fontes que eles năo leram; năo devem preferencialmente citar seu próprio trabalho ou de seus amigos, de seus pares ou de publicaçóes da instituiçăo em que atuam.

- Autores devem evitar citar trabalhos de apenas um país;

- Autores năo devem usar um número excessivo de citaçóes para dar suporte a apenas um argumento;

- Idealmente, autores devem citar fontes que passaram por avaliaçăo entre pares sempre que possível;

- Autores náo devem citar propagandas ou material propagandístico. ${ }^{3}$

Fonte: Revista Bioinformatics. Disponível em: http://www.biomedcentral.com/getpublished/ editorial-policies\#citations

É possível perceber, com base nessas orientaçôes, a quantidade de variáveis que podem estar em jogo na análise de um manuscrito, apenas no que se refere ao processo de citaçăo e de elaboraçăo das referências. Estas variáveis săo também dimensôes do letramento que permanecem "escondidas" nas diretrizes para autores de todas as revistas, com exceçăo da Bioinformatics, e que podem, portanto, configurarem-se como barreiras na elaboraçâo de manuscritos por parte de qualquer autor, sejam pesquisadores iniciantes ou mais experientes, já que fazem parte dos critérios de análise dos pareceristas, mas năo sâo disponibilizadas para o conhecimento dos autores.

17 Traduçâo livre. No original: "- Any statement in the manuscript that relies on external sources of information (i.e. not the authors' own new ideas or findings or general knowledge) should use a citation; Authors should avoid citing derivations of original work. For example, they should cite the original work rather than a review article that cites an original work; - Authors should ensure that their citations are accurate (i.e. they should ensure the citation supports the statement made in their manuscript and should not misrepresent another work by citing it if it does not support the point the authors wish to make); - Authors should not cite sources that they have not read; Authors should not preferentially cite their own or their friends', peers', or institution's publications; - Authors should avoid citing work solely from one country; - Authors should not use an excessive number of citations to support one point; - Ideally, authors should cite sources that have undergone peer review where possible; - Authors should not cite advertisements or advertorial material". 
Esses ocultamentos săo também justificados por presumidos sociais do gênero do discurso. O processo de citaçăo é item elementar das boas práticas acadêmicas e, portanto, tende a ser abordado por toda disciplina de metodologia científica. Assim, é tomado como sabido, inclusive por pesquisadores iniciantes, informaçôes a respeito de quando e como citar. Entretanto, como verificado nas diretrizes para citaçăo da Bioinformatics, nem todas as orientaçóes referem-se às especificidades do discurso científico de que falam Delcambre e Lahanier-Reuter (2015), tais como a terceira, por exemplo, que preza pela importância de a citaçăo ser fidedigna às ideias defendidas pelo autor para que a citaçâo garanta, de fato, os direitos autorais do mesmo. Muitas das orientaçóes, assim como tudo o que se refere à linguagem, demarcam posiçóes ideológicas das revistas, como evidenciado na orientaçăo de número seis: evitar citar trabalhos de apenas um país. Assim, ainda que todos os autores dominassem os processos de citaçáo no discurso acadêmico, continuaria a ser necessária uma explicitaçấo das dimensóes do letramento no que se refere a esse respeito, de modo a assegurar que autores, pareceristas e editores comunguem do maior número de especificidades esperadas para a comunicaçăo escrita naquele evento de letramento.

\section{CONSIDERAÇÕES FINAIS}

A análise dos textos referentes aos direitos dos autores, políticas de autoria, estilo dos textos e processo de submissăo de manuscritos presentes nas diretrizes para autores de seis revistas de CC revelou ocorrências de dimensôes "escondidas" do letramento, cujas razóes debruçam-se em presumidos sociais do gênero artigo de pesquisa, evidenciados, na presente pesquisa, a partir de uma análise etnográfica discursiva dos textos, a qual revelou os conceitos de língua, texto e gênero que fundamentam as práticas de letramento das revistas, bem como as orientaçôes dadas aos autores e os presumidos sociais que levam a tais ocultamentos.

Verificamos que, embora as revistas possuam uma visăo social de língua escrita, possuem uma visáo estrutural de texto que, apesar de servirem a propósitos sociais, caracterizam-se por convençôes linguísticas específicas da esfera de atividade humana em que circulam, as quais sâo compartilhadas todos os textos de todos os gêneros daquela esfera. Essa visâo de língua, texto e gênero se assemelha à abordagem de ensino de letramento, identificada por Lea e Street (1998) como socializaçâo acadêmica, o qual ignora as diferenças entre as práticas sociais e as práticas de letramento dentro de uma esfera específica, como a acadêmico-científica, e, portanto, acredita na existência de um discurso acadêmico único que é transferível a todos os gêneros.

Essa visăo de letramento fundamenta determinados presumidos sociais que levaram ao ocultamento de diversas orientaçóes nas diretrizes analisadas. Tais dimensóes "escondidas" do letramento podem ser a causa de um número tăo alto de reprovaçăo de manuscritos por parte das revistas. Isto porque, como evidenciado nesta pesquisa, esses ocultamentos impedem que autores e parecerista tenham em mente as mesmas expectativas sobre o que seja um bom artigo de pesquisa, digno de ser aceito por aquela revista para ser publicado.

Segundo o editor da revista Bioinformatics, o número de manuscritos rejeitados varia de ano para ano, mas estima-se que cerca de $50 \%$ das submissóes săo reprovadas. 
Quando se olha para a revista TIST, os números săo ainda mais assustadores. Segundo o editor da revista, seu último relatório revelou que apenas 19\% dos manuscritos submetidos foram aprovados. Para melhorar esses números, é preciso que as revistas explicitem ao máximo as orientaçóes para a elaboraçăo dos manuscritos, năo só no que se refere à formataçáo e à estrutura dos artigos, mas também no que diz respeito ao conteúdo, retórica e discursos esperados/aceitáveis. É preciso também que essas explicitaçôes abarquem questôes ideológicas das revistas, que săo impossíveis de prever, ajudando pesquisadores novatos e experientes a antecipar o que se espera deles na comunicaçăo acadêmica naquele evento de letramento específico. 


\section{REFERÊNCIAS BIBLIOGRÁFICAS}

ARANHA, S. The development of a genre-based writing course for graduate students in two fields. In: BAZERMAN, C..; BONINI, A.; DE CARVALHO FIGUEIREDO, D. (org.). Genre in a changing world. X ed. Santa Barbara, CA: The WAC Clearinghouse and Parlor Press, 2009, pp. 465-482.

BAKHTIN, M. M. The Dialogic Imagination.Austin:University of Texas Press, (1981)1997. CANDLIN, C.N. Prefácio a Bhatia. In: BHATIA, V. Analysing genre: language in professinal settings. London: Longman, 1993.

CLAPHAM, P. Publish or perish. BioScience, v. 55, n. 5, pp. 390-391, 2005.

CORRÊA, M. L. G. As perspectivas etnográfica e discursiva no ensino da escrita: o exemplo de textos de pré-universitários. Revista da ABRALIN, v. 10, n. 4, pp. 333-356, 2011.

DELCAMBRE, I.; LAHANIER-REUTER, D. Discurso de outrem e letramentos universitários. In: RINCK, F.; BOCH, F.; ASSIS, J. A. (org.). Letramento e formaçáo universitária: formar para a escrita e pela escrita. Campinas: Mercado de Letras, 2015, pp. 225-250.

FISCHER, A. "Hidden Features" and "Overt Instruction" in academic literacy practices: a case study in engineering. Working With Academic Literacies: Case Studies Towards Transformative Practice. Local: Editora, 2016, pp. 75-85.

GEE, J.P. New times and new literacies. In: VARNAVA-SKOURA, G., KALANTZIS, M.; $\mathrm{COPE}, \mathrm{B}$ (eds). Learning for the future: New worlds, new literacies, new learning, new people, Australia: Common Ground Publishing, 2002, pp. 59-83.

HENDERSON, R.; EXLEY, B. Planning for literacy learning. In: HENDERSON, R. (Ed.). Teaching literacies: Pedagogies and diversity in the middle years, South Melbourne, Vic: Oxford University Press, 2012, pp. 19-51.

HYLAND, K. Genre: Language, context, and literacy. Annual review of applied linguistics, v. 22, pp. 113-135, 2002.

Genre-based pedagogies: A social response to process. Journal of Second Language Writing, v.12, pp. 17-29, 2003.

IVANIČ, R. Writing and Identity: The discoursal construction of identity in academic writing. Amsterdam: John Benjamins, 1998.

KOMESU, F. Letramentos acadêmicos e multimodalidade em contexto de EaD semipresencial. Scripta, v. 16, n. 30, pp. 75-90, 2012.

.Concepçăo (ôes) de texto em contexto de EaD semipresencial. Filologia e Linguística Portuguesa, pp. 305-333, 2013.

LEA, M. R.; STREET, B. V. Student writing in higher education: An academic literacies approach. In: __. Studies in Higher Education, Abingdon, Oxon, UK, v. 23, n. 2, 1998, pp. 157-172.

LILLIS, T. Whose 'Common Sense'? Essayist literacy and the institutional practice of mystery. In: JONES, C.; TURNER, J.; STREET, B. Students Writing in the University: Cultural and epistemological issues. Amsterdam: John Benjamins, 1999. pp. 127-140. 
MAGALHĂES, I. Letramento, intertextualidade e prática social crítica. In: (org.). Discursos e práticas de letramento: pesquisa etnográfica e formaçâo de professores. Campinas, SP: Mercado de letras, 2012a, pp. 17-68

Letramentos e identidades no ensino especial. In: . (org.). Discursos e práticas

de letramento: pesquisa etnográfica e formaçăo de professores. Campinas, SP: Mercado de letras, 2012b, pp. 159-194

MOTTA-ROTH, D. A importância do conceito de gêneros discursivos no ensino da redaçâo acadêmica. Intercâmbio, vol VIII, pp. 119-128, 1999.

OLIVEIRA, E. F. Letramento Acadêmico: principais abordagens sobre a escrita dos alunos no ensino superior. II Encontro Memorial do ICHS, pp. 1-10, 2009.

OLIVEIRA, M. do S. Gêneros textuais e letramento. Revista Brasileira de Linguística Aplicada, v. 10, n. 2, pp. 325-345, 2010.

STREET, B. Literacy in Theory and Practice. Cambridge: CUP, 1984.

Academic Literacies. In: JONES, C.; TURNER, J.; STREET, B. Students Writing in the University: Cultural and Epstemological Issues. London: John Benjamins Publishing Company, 2000, pp. 193-199.

. Literacies across education contexts. Philadelphia: Castlon Publishers, 2005.

Academic Literacies and the 'New Orders': implications for research and practice . Debates in Higher Education Seminar, UCL Centre for the Advancement of Learning and Teaching. 04/12/2007.

. Traduçâo: Armando Silveiro. Dimensōes "escondidas" na escrita de artigos acadêmicos. Perspectiva, v. 28, n. 2, pp. 541-567, jul./dez. 2010.

. Eventos de letramento e práticas de letramento: teoria e prática nos novos estudos de letramento. In: MAGALHÂES, I. (org.). Discursos e práticas de letramento: pesquisa etnográfica e formaçăo de professores. Campinas, SP: Mercado de letras, 2012, pp. 69-92 SWALES, J. M. Genre Analysis: English in Academic and Research Settings. Cambridge: Cambridge University Press, 1990.

TENUTA, A. M.; OLIVEIRA, A. L. A. M. Livros didáticos e ensino de línguas estrangeiras: a produçăo escrita no PNLD-2011/LEM. Revista Linguagem \& Ensino, v. 14, n. 2, pp. 315336, 2012.

VIEIRA, B. G. A. M. A disciplina Metodologia Científica - Redaçâo e Documentaçăo Técnica e a promoçấo do letramento acadêmico de graduandos em Ciência da Computaçâo: uma análise qualitativa. $5^{\circ}$ CIAIQ v. 1, pp. 662-671, 2016. 